JERZY NIKITOROWICZ

E-MAIL: JERZYNIKI@WP.PL

\title{
KU JAKIM STRATEGIOM \\ W EDUKACJI MIĘDZYKULTUROWEJ \\ W KONTEKŚCIE WSPÓŁCZESNYCH PROBLEMÓW \\ WIELOKULTUROWOŚCI?
}

\section{Założenia wstępne}

Edukacja międzykulturowa rozwija się w kontekście narastających problemów wielokulturowego świata, wielonarodowych i wielowyznaniowych państw, trudnego procesu kształtowania się demokratycznych społeczeństw wielokulturowych. Obecnie kulturowe poczucie wspólnoty wydaje się być niemożliwe bez wsparcia ekonomicznego, bez korzystnej pozycji tej wspólnoty w strukturach państwa, bez znaczącego miejsca w stratyfikacji społecznej i korzystania z zasobów ekonomiczno-gospodarczych. Stąd istotne wydają się być następujące pytania: w jakim zakresie określone grupy kulturowe, jej reprezentanci, uczestniczą w życiu społeczno-politycznym określonego kraju? Czy i w jakim zakresie formułowane są oskarżenia wobec funkcjonujących grup kulturowych w danym kraju w kontekście pogłębiającego się zróżnicowania ekonomicznego, wzrostu wzajemnych niechęci, odżywania złej pamięci, nieufności, nacjonalizmu, ksenofobii, megalomanii, rasizmu, terroryzmu?

Kultura, jako czynnik różnicujący, może zamykać tożsamościowo lub otwierać na Innych i ich kultury. Jednak ten proces zawsze dzieje się w określonych warunkach społecznych, kulturowych, ekonomicznych, politycznych. W zależności od warunków, określonego kontekstu, każda grupa narodowościowa, etniczna czy religijno-wyznaniowa poszukuje sposobów zachowania określonych wartości, korzystnej pozycji w strukturach, w określonej stratyfikacji społecznej, korzystania z zasobów gospodarczych, ekonomicznych. Problemem ustawicznym było i jest to, w jakim zakresie i stopniu były te grupy uznawane i szanowane. W historii niejednokrotnie edukacja była i często jest także obecnie czynnikiem indoktrynacji społeczno-politycznej, czynnikiem asymilacji, podporządkowania, 
marginalizacji, stygmatyzacji. Stąd też zauważamy obecnie w państwach narodowych, które wydają się dobrze funkcjonować w erze globalizacji, negatywne skutki prowadzonej edukacji na bazie polityki różnicy. Opierała się ona na separatyzmie, kreowaniu tożsamości narodowej w opozycji do siebie, sąsiadów, narodów historycznie i mentalnie pokrewnych. Przykładem może być sytuacja wytworzona po upadku ZSRR, gdy każdy z wyzwolonych narodów zaczął „komponować” swoją kulturową tożsamość w opozycji do drugiego. Obecnie niewiele się zbliżyliśmy w rozumieniu siebie i porozumieniu ze sobą i w dalszym ciągu powstaje rozbieżność interesów, mnożą się podziały, sprzeczności, wzrasta wzajemna nieufność, lęki, poczucie zagrożenia i w efekcie partnerstwo wschodnie wydaje się być poważnie zagrożone.

W kontekście powyższego należy także zwrócić uwagę na podkreślane w ostatnich latach negatywne skutki polityki wielokulturowości opartej na liberalizmie (poprawności politycznej, relatywizmie kulturowym), jednostronnie i populistycznie formułowanych zasadach obywatelstwa i demokracji. Zaczęto nawet wskazywać na upadek idei i zasad mulikulti, zapominając, że byliśmy i jesteśmy w trudnym i długotrwałym procesie, w którym występowały i będą występowały niepowodzenia i porażki. Uważam, że jesteśmy jakby wpisani w model „dezintegracji pozytywnej” i nasze działania edukacyjne immanentnie związane są z dezintegracją pozytywną. Mamy i będziemy mieli do czynienia z różnymi prądami, które będą się ścierały, nakładały na siebie, będą „falowały” idee emancypacji versus dominacji, paradygmatu dialogu i współistnienia versus walki i zwalczania się. Mamy do czynienia z ruchliwością horyzontalną i wertykalną, wzrostem anonimowości, problemem niechęci do stałych i długotrwałych zobowiązań, zmiennością idei, niechęcią długotrwałego przywiązania do idei i do ludzi, unikania stałego zdefiniowania. Cytujemy ustawicznie prace Z. Baumana i posługujemy się metaforą turysty czy włóczęgi w procesie kreowania tożsamości. Wiemy, jak wiele jest i może być społeczno-kulturowych identyfikacji, analizujemy dylematy lojalności w kontekście przynależności i aspirowania do przynależności. Wskazujemy na fragmentaryzację tożsamości, niezdefiniowaną, niegotową, wielopłaszczyznową, kontekstualną, z gorsetem aksjologii administracyjnej.

Chciałbym zauważyć i podkreślić, że w edukacji międzykulturowej różnicę i inność traktowaliśmy i traktujemy jako kapitał kulturowy, kapitał, którym człowiek dysponuje, z którego może wybierać. Zadaniem edukacji jest uświadomienie bogactwa i możliwości wyboru, uświadomienie tego 
daru i mocy tożsamościowej przez niwelowanie lęków i odczuwanego stygmatu, doprowadzenie do świadomego i odpowiedzialnego wyboru.

\section{Problemy z wielokulturowością}

Uważam, że idea i wizja społeczeństw wielokulturowych przeżywa poważny kryzys, głównie w kontekście wykreowanych i realizowanych w cywilizacji Zachodu zasad relatywizmu kulturowego i poprawności politycznej, które w efekcie prowadzą do wykluczania tożsamościowego i marginalizacji nie tylko imigrantów, ale także obywateli kraju ich przyjmującego. Bezrefleksyjne posługiwanie się kanonem relatywizmu i politycznej poprawności, uznanie wszystkich kultur za równe z pewnością było reakcją na negatywne zjawiska wcześniejszej dominacji, hegemonii, panowania jednej kultury nad innymi. Do takich działań przyczynił się z pewnością upadek imperiów, kolonializm, dwie wojny światowe. Świadomość o wyższości cywilizacji Zachodu, niosącej postęp, będącej źródłem wolności, sprawiedliwości, poddana została krytyce i samokrytyce w kontekście „wyprodukowanych” reżimów komunizmu i nazizmu odpowiedzialnych za śmierć milionów ludzi. To tak, jakby elity reprezentujące kulturę Zachodu dokonały internalizacji winy za kolonializm, komunizm, nazizm i jednocześnie utraciły wiarę w dotychczasowe wartości, stopniowo rezygnując z nich. W tym kontekście, m.in., zostały określone i przyjęte idee pluralizmu kulturowego, uznające równość kultur i z tym związany relatywizm kulturowy, wyrażanie szacunku i uznania do innych bezwarunkowo, powstrzymywanie się od ocen i wartościowania stylu życia i zachowań bez wymagań i zobowiązań, otwarcie na dialog i porozumienie ze względu na doznane przykrości. Jakby zapomniano, że istotą zdążania ku społeczeństwu wielokulturowemu jest złożony i długotrwały proces, powolne nabywanie umiejętności przechodzenia od reakcji na odmienność, gdzie często występuje brak zrozumienia, megalomania, ksenofobia, uprzedzenia, bazowanie na stereotypach, do interakcji, czyli celowego poznawania, zrozumienia, współpracy, współdziałania, negocjacji, ustawicznego dialogu informacyjnego i negocjacyjnego. Stąd coraz częściej formułujemy w naszych publikacjach z zakresu edukacji międzykulturowej, m.in. takie pytania, jak: czy grupy dominujące są świadome swojej roli i zadań wobec własnej kultury i kultury grup mniejszościowych, czy treści kultury grupy większościowej są prezentowane grupom mniejszościowym, w jakich formach, czy kultura grup mniejszościowych różnego typu i wymiaru znajduje odzwierciedlenie 
w kulturze grupy większościowej, czy jest i może być reprezentacją kultury regionu, narodu, cywilizacji, jaka jest wizja ról społeczno-kulturowych i jak wypracowywać sposoby wspierania ludzi i grup w osiąganiu kulturowych wartości?

Podejmując próby odpowiedzi na powyższe pytania wielokulturowość traktuję i analizuję nie tylko jako współwystępowanie na tej samej przestrzeni grup o odmiennych kulturowych cechach, ale przede wszystkim jako zjawisko tożsamościowe, ideologiczne i edukacyjne, co pozwala zauważyć i wskazać na nowe strategie w edukacji międzykulturowej skierowane bardziej ku grupom dominującym, większościowym niż mniejszościowym. To właśnie one będą decydowały o efektach prowadzonego dialogu w trudnym procesie kształtowania się społeczeństw wielokulturowych. „ważne jest nie tylko to, że wielość jest rzeczywiście wszędzie, ale zwłaszcza to, że w rozmaitej postaci jest zgodna $\mathrm{z}$ wizją prawdziwej, pełnej treści wolności” [Welsch 1998: 179-180]. Istotą wielokulturowości z edukacyjnego punktu widzenia nie jest więc współwystępowanie na tej samej przestrzeni dwóch lub więcej grup społecznych o odmiennych kulturowych cechach dystynktywnych, jak podkreśla Marian Golka [1997: 54-55]. Tak rozumiana wielokulturowość nie wskazuje na dynamikę ani na aktywność, jak też na liczbę i jakość reakcji na Inność i interakcji z Innością, czy określone kierunki i efekty form kontaktów. Nie zakłada współpracy środowisk, interakcji między nimi, podejmowania i realizacji zadań związanych z kultywowaniem kultury rodzimej i zadań obywatelskich. Mamy wskazanie, że wielokulturowość to zjawisko społeczne w postaci współwystępowania odmienności, czyli mamy fakt empiryczny. Uważam, że tak rozumianą wielokulturowość mieliśmy od zawsze, od czasów plemiennych; zjawisko charakteryzujące się występowaniem na określonym terytorium zróżnicowania kulturowego w różnym zakresie. Tak więc traktowanie wielokulturowości jako występowania kultur na określonej przestrzeni nie odpowiada społecznej rzeczywistości, gdyż kultury jako zjawiska dynamiczne wchodzą w wielorakie interakcje. Analizując historię obszarów wielokulturowych stwierdzimy, że życie na nich nie była idyllą, że były te obszary i są nadal miejscami napięć, konfliktów i niejednokrotnie wojen.

Sądzę, że obecnie istotą fenomenu wielokulturowości jest ogniskowanie się na interpretacjach tożsamości społeczno-kulturowej, na sporach o autonomię i podmiotowość współczesnego człowieka. Tożsamość stała się bowiem kategorią opisującą i analizującą rzeczywistość i coraz częściej jest przedstawiana w ustawicznym, zmiennym, kontekstualnym i nieprzewidywalnym rozwoju. 
Zjawisko tożsamościowe, inaczej fakt świadomościowy, to samodefiniowanie przynależności do dwóch lub kilku kultur, uznawanie jej norm, wartości i sankcji, jak też przewidywanie konfliktów wewnętrznych i możliwości ich rozwiązywania. Zjawisko to jest wynikiem odpowiedzialnego i wolnego w wyborze samookreślenia jednostki, świadomego przyjęcia na siebie zadania w określonej przestrzeni społeczno-kulturowej, usytuowania się $\mathrm{w}$ relacjach $\mathrm{z}$ innymi ludźmi, określenia hierarchii wartości, zasad i norm postępowania. W warunkach współczesnej wielokulturowości bezrefleksyjna lojalność wobec wartości rodzimej grupy zastąpiona została wieloma ofertami, zróżnicowanymi systemami aksjologicznymi i teleologicznymi, całą gamą ideologii i manipulacji o różnym zakresie i zasięgu. Stąd tożsamość to drogowskazy, priorytety pozwalające określić i zrozumieć swoje miejsce w rodzinie, grupie familijno-parafialnej, w społeczności lokalnej, państwie, świecie. Cała gama przemian społeczno-politycznych, ekonomicznych, kulturowych, komunikacyjnych wymuszają myślenie, wewnętrzną i zewnętrzną dyskusję nad tym kim jestem i kim się staję w wymiarze jednostkowym i zbiorowym. To powoduje ustawiczne redefiniowanie przynależności i kolejnych identyfikacji, poczynając od rodziny aż do globalnych odniesień.

Zjawisko ideologiczne, czyli kierowanie się określonymi normami i wartościami, określanie i podejmowanie zobowiązań etyczno-moralnych wobec własnej kultury i innych kultur, powoływanie i wspieranie środowisk opiniotwórczych, organizacji, stowarzyszeń, fundacji w celu wzajemnego zrozumienia, porozumienia, współpracy, wychowania dla pokoju, kształtowania i realizowania określonych idei związanych z realizacją paradygmatu współistnienia. Idee wielokulturowości miały uruchomić i realizować proces współpracy i współdziałania na zasadach partnerskich, podejmując działania niwelujące napięcia i konflikty, jak też wspierające i wyrównujące możliwości i szanse zróżnicowanych grup. Czy tak się stało, czy takie procesy zachodzą? Czy współczesna wielokulturowość tworzy przestrzeń, w której różne wspólnoty i kultury wchodzą wzajemnie w interakcje, poznają się w tym procesie i tworzą kulturowe wspólnoty na bazie wzajemnego zaufania, z określonymi wizjami rozwoju, zasadami i normami funkcjonowania, wspólnymi wartościami i szacunkiem do jednoczącego dane społeczeństwo prawa?

Wielokulturowość rozumiana jako system ideologiczny była i jest związaną z określoną polityką. 
Środowiska opiniotwórcze przedstawiają współistnienie wielu grup kulturowych w ramach jednego systemu politycznego jako wartość pozytywną i gdy uda im się przekonać do tego poglądu znaczą część społeczeństwa, skonstruować instytucje dbające o to współistnienie i wprowadzić, choćby częściowo idee wielokulturowości do praktyki społecznej (polityki) [Mucha 1999: 42].

W Wielkiej Brytanii, jak pisze B. Szlachta [2006: 73], stosunki między grupami kulturowymi miały polegać na naturalnym procesie wzbogacania brytyjskości przez elementy kultur imigranckich. Brytyjskość była rozumiana jako suma, tego co angielskie, szkockie i walijskie. W USA wielokulturowość oznaczała afirmację tożsamości i podkreślanie inności związanej z rasą, językiem, klasą społeczną, etnicznością. Do tego afirmacja ta była wspierana przez ruchy obrony praw obywatelskich. Sądzę, że wielokulturowość w USA oznaczała odpór dla melting pot - tygla. Początkowo kultury w USA ukierunkowano ku asymilacji, stosując metaforę melting pot, co oznaczało tygiel/garnek, w którym mieszają się i zleją się w jedno różne składniki i w efekcie otrzymamy „strawną” potrawę. Obecnie można powiedzieć, że to już historia tego tradycyjnego modelu wielokulturowości. Nastąpiło ewoluowanie w kierunku podtrzymywania tożsamości kulturowej (kultur narodowych) poszczególnych grup narodowych i etnicznych. Pojawiła się metafora salad bowl, oznaczająca wiele składników sałatki, które mieszają się, ale nie tracą swoich wartości, a ich odmienność jest wyraźnie widoczna. Mogą być polane integrującym sosem, doprawione majonezem i na zewnątrz mogą być widziane jako całość zespolona (jeden naród amerykański). Kanada położyła nacisk na kultywowanie odrębności kultur (cultural mosaic - mozaika kulturowa) wskazując, że mieszkańcy Kanady powinni uczyć się przede wszystkim jak razem żyć we własnym kraju. Australijczycy przejęli ten termin od Kanadyjczyków, ale używali pojęcia wielokulturowości w innym znaczeniu, największe znaczenie przypisując kulturze dominującej i językowi angielskiemu, odmiennie niż w Kanadzie.

Zjawisko edukacyjne jest związane z kreowaniem systemu edukacyjnego ukierunkowanego na inicjowanie i realizowanie dialogu międzykulturowego przez realizację projektów i programów kształtujących postawy otwartości, zrozumienia i porozumienia z innymi kulturami, doświadczanie inności kulturowej i uwrażliwianie na nią. Według Wojciecha Burszty, doświadczenie zróżnicowania kultur świata jako zróżnicowania deklaratywnie równoprawnych kultur, tożsame jest $\mathrm{z}$ utrwaleniem się całościowej koncepcji kultury. Pojęcie kultury uzyskuje przez to walor operacyjny i uniwersalny, dzięki czemu rozumienie „różnicy kulturowej” wynika z uprzed- 
niego ustalenia, że wielokulturowość świata jest faktem, a zadaniem nauki jest jego opisywanie i wyjaśnienie [Burszta 1997: 25]. Jest to zadanie trudne do wykonania, nie tylko ze względu na złożoność i interdyscyplinarny charakter problematyki, ale również z uwagi na obiektywne okoliczności. Kwestie wzajemnych stosunków różniących się między sobą jednostek czy grup stanowiły i stanowią zazwyczaj obszar drażliwy i rzadko do niedawna eksponowany w badaniach naukowych.

Wielokulturowość jako fakt edukacyjny jest efektem zachodzących ustawicznie zmian tożsamościowych i ideologicznych, stanu świadomości różnic kulturowych, akceptacji odmienności i „inności”, poszanowania wartości i symboli innych kultur oraz traktowanie wielokulturowości jako pewnego normatywnego programu o charakterze postulatywnym. Stąd już od dwudziestu lat w działaniach Katedry Edukacji Międzykulturowej promujemy wielokulturowość jako wartość, a interakcje z Innymi jako niezbędny element własnego rozwoju i możliwość kształtowania wrażliwości wobec Innych. Nasza działalność edukacyjna w tym zakresie to już nie postulowanie i nadzieja na pokój i godne życie jednostek, grup czy narodów, a konkretne działania skierowane do różnych grup wiekowych i środowisk. Realizowane przez nas projekty edukacyjne i systematyczne zajęcia ze studentami pozwalają twierdzić, że wyszliśmy w rozumieniu wielokulturowości poza program o charakterze postulatywnym. Prowadzona przez nas działalność edukacyjna nie narzucała idei wielokulturowości jako politycznie poprawnego punktu widzenia, a podejmuje próby niwelowania uprzedzeń i stereotypów, funkcjonujących i podtrzymywanych mitów edukacyjnych. Staramy się z jednej strony dostrzegać i eksponować „dobrą pamięć”, pozytywne strony, doznania i wartości, z drugiej zaś wskazywać i analizować w kontekście „współczynnika humanistycznego” Floriana Znanieckiego „złą pamięć”, negatywne nastawienia, krzywdy i upokorzenia mające miejsce w kontaktach odmiennych kultur. Nie kreujemy jednostronnego obrazu wielokulturowej przeszłości jako stanu harmonii, a próbujemy poszukiwać źródeł napięć i konfliktów, skutków dominacji politycznej i kulturowej jednej kultury nad drugą, analizować w różnych ujęciach i kontekstach pogranicze stykowe i przejściowe, treściowe i świadomościowe, mając na uwadze troskę i dbałość o wspólny spadek pogranicza grup etnicznych, narodów słowiańskich i wyznań.

Uważam, że w pewnym stopniu nasza praca przyczyniła się do nobilitacji wielokulturowej historii regionów i miejscowości, jej odkrywania, rewitalizacji, upamiętniania. Obecnie wielokulturowość stała się strategią 
wykorzystywaną $\mathrm{w}$ promocji wielu miast (m.in. Białegostoku, Lublina, Wrocławia, Gdańska, Łodzi) ${ }^{1}$.

$\mathrm{Z}$ moich wieloletnich doświadczeń wynika, że niezbędna jest nowa polityka edukacyjna $\mathrm{w}$ tym zakresie, polityka prowadząca do nabycia świadomości przez każdego obywatela globu ziemskiego o zróżnicowaniu światopoglądowym, etnicznym, religijnym. Edukacyjna polityka wielokulturowości winna doprowadzić do nabycia umiejętności przekraczania własnego etnocentryzmu i socjocentryzmu, zrozumienia i porozumienia z Innymi. Kiedy przygotowywałem książkę dla Gdańskiego Wydawnictwa Psychologicznego na temat grup etnicznych w wielokulturowym świecie zwróciłem uwage, że w byłym ZSRR etnosy na tym rozległym obszarze żyły własnym życiem, kierując się swoimi wartościami i zasadami, a budowanie ZSRR przebiegało na odrębnych zasadach materializmu, których nie uznawały liczne etnosy. Można uznać, że nikt nikomu nie przeszkadzał i nie zagrażał, jedni i drudzy żyli swoim życiem. Jedni udawali, że etnosów nie ma, a drudzy nie wiedzieli i nie chcieli wiedzieć o ideologii społeczeństwa socjalistycznego i nie zagrażali budowie Związku Socjalistycznych Republik Radzieckich.

Można powiedzieć, że była to strategia niedopuszczająca do otwartego antagonizmu, inaczej strategia ukrytego antagonizmu. Można także wskazywać i analizować izolację jawną lub ukrytą, a także koegzystencję pozorną. To już historia i realizacja takiej strategii jest obecnie niemożliwa, stąd wielowątkowo rozumiem i traktuję wielokulturowość, gdyż sprzyja to kreowaniu społeczeństw wielokulturowych, wskazuje na dynamikę współwystępowania odmienności o różnym charakterze, tworzy niezbędne warunki i sytuacje, wyzwala naturalne reakcje i interakcje wobec siebie. Może mieć miejsce zjawisko symetrycznej akulturacji, przenikania wzajemnego, wzajemnego uczestniczenia w życiu społeczno-kulturowym, podejmowania i rozwiązywania wielu problemów lokalnych, regionalnych, co może prowadzić do powstania uporządkowanych struktur społecznych, jak wskazuje Grzegorz Babiński [1997]. Może jednak nie dochodzić do powyższego i wytworzona publiczna przestrzeń nie będzie motywowała ku interakcjom i tym samym nie będzie proponowała rozwiązań pluralistycznych. Właśnie dlatego tak ważna jest edukacja, świadomość wyborów, identyfikacje. Idea społeczeństw wielokulturowych zakłada akceptację różnorodności, istnienie pojedynczych kultur w sferze publicznej (prawo, ekonomia, polityka, edukacja) oraz prywatnej (zasady życia społecznego, wierzenia, moralność, obyczaje, zrzeszanie się, powoływanie stowarzyszeń,

Szerzej na ten temat m.in. [Angutek, praca zbiorowa przygotowywana do wydania]. 
organizacji w kontekście ochrony wartości, tradycji i realizacji własnych potrzeb). Należy jednak zauważyć, że granice akceptacji i tolerancji różnorodności mogą być zmienne i może mieć miejsce sprzeczność w kontekście postrzegania humanistycznego funkcjonującego prawa i powinności obywatelskich. Nie zawsze bowiem wielokulturowość ukierunkowana ku społeczeństwu wielokulturowemu jest skutkiem wyboru, a może być często wynikiem zaistniałej sytuacji politycznej, społecznej, gospodarczej. Związki i reakcje mogą mieć więc przekrój od pokojowego współistnienia do agresji, przemocy i terroryzmu, stąd wskazuje się na wagę kontaktów, wzajemne uczestnictwo w życiu szerszej zbiorowości, przenikanie się wartości. Paweł Boski [2008: 165-205] omawiając zjawisko wielokulturowości na poziomie makrospołecznym zwrócił uwagę, że w miejsce życia obok promowane jest aktywne uczestnictwo wszystkich zainteresowanych podmiotów, co wspierają i czego strzegą organy władzy państwowej.

W kontekście powyższego uważam, że w trudnym procesie kształtowania się społeczeństw wielokulturowych niezbędne jest zauważanie i uwzględnianie powyższych faktów-zjawisk społecznych, tożsamościowych, ideologicznych i edukacyjnych. W obecnych warunkach wielokulturowości ustawicznie jest wyzwalane porównywanie, uświadamianie różnic, potrzeba odpowiedzi na pytania: kim jestem? Kim chcę być? Kim powinienem być? Jakie wartości dopuszczane są w kontekście uznawanego kanonu kulturowego? Jaką mam hierarchię potrzeb w tym zakresie? Jakie autorytety wspierają mnie w kształtowaniu tożsamości społeczno-kulturowej i jednostkowej? Jak łączę wartości rdzenne - podstawowe z uniwersalnymi, globalnymi?

\section{Ku jakim strategiom w edukacji międzykulturowej?}

Edukacja międzykulturowa mając na uwadze idee i różne sposoby odczytywania wielokulturowości bazowała i winna w dalszym ciągu bazować na perspektywie emancypacji, wyrażać sprzeciw homogenizmowi, opresjonowaniu mniejszości, ksenofobii i megalomanii. Idee emancypacji doprowadziły do rezygnacji z ukrywania kulturowej odmienności, do jej rewitalizacji; odbudowy wartości uśpionych lub wycofanych, rezygnacji z nieautentyczności, udawania, schizofrenicznego funkcjonowania i kreowania tożsamości rozszczepionej. Przeciwstawiano się dominacji kulturowej, zamknięciu kulturowemu i tym samym ukierunkowano się ku autonomii i poczuciu godności w obronie własnych wartości. Zdaniem badaczki 
multikulturalizm jest względnie spójną doktryną emancypacji politycznej dyskryminowanych grup kulturowych, których członkowie, uważając swoje kultury za autentyczne i odrębne od innych, roszczą sobie prawo do równania siebie i swoich kultur z kulturą dominującą w sferze publicznej [Kurczewska 1997: 49].

Podejmując wiele działań edukacyjnych zdawaliśmy i zdajemy sprawę, że nie jest możliwa całkowita niwelacja lęków historycznych, mitów, uprzedzeń, kompleksów, stereotypów negatywnych, odczuwanego i podsycanego zagrożenia. Z naszych analiz i badań wynika, tak jak wskazywał George Herbert Mead, że kształtująca się ustawicznie tożsamość jest efektem interakcji. Problemem jednak są zakodowane w umysłach dogmaty, lęki, urazy, uprzedzenia, a także ich rozbudowywanie w kontekście zranionej, skrzywdzonej tożsamości. Winniśmy więc w pracy edukacyjnej szczególne miejsce przeznaczyć na problem odczuwania krzywdy, inaczej piętna, na co zwracał uwagę w swojej koncepcji Erving Goffman, na wyobrażanie świata nieprzyjaznego, zaborczego, niewykraczania poza wyobrażenia i mity z jednoczesnym kreowaniem kolejnych mitów i lęków. Uznaliśmy, że tylko systematyczna i zespołowa praca może przynieść efekty. Uważam, że najlepiej oddaje naszą pracę metafora falowania - przypływów i odpływów, fal burzliwych i spokojnych, jakby uśpionych, przechodzenia, nakładania się silnych i groźnych na słabe i spokojne aż do wystąpienia tsunami.

Tak postrzegam i odbieram współczesne problemy wielokulturowości i efekty edukacji międzykulturowej, skutki współbycia-współistnienia odmiennych kulturowo grup na wspólnym terytorium. Zdaję sobie sprawę z nieodwracalności pewnych procesów i jednocześnie mam świadomość istoty polifoniczności, której nie można zaprzepaścić i utracić. Nie ma bowiem możliwości zatrzymania postępującego zróżnicowania w rozmaitych wymiarach i warstwach funkcjonowania człowieka i jego kultury. Jest to pewnego rodzaju antidotum wobec postępującej utraty wzajemnej ufności, wspólnotowości i spójności wartości i norm. Miałem przyjemność uczestniczenia w koncercie muzyki polifonicznej gruzińskiego zespołu SAKHIOBA w Operze i Filharmonii Podlaskiej. Uświadomiłem jeszcze bardziej znaczenie wielości głosów połączonych w muzyczną całość z jednoczesnym brzmieniem kilku samodzielnych melodii. Można było je usłyszeć i śledzić ich samodzielne istnienie, można wyodrębnić z całości, aby zaistniały samodzielnie, jednak nie byłoby istoty wspólnotowości, więzi między nimi i efektu siły i piękna przeżyć, oddziaływania na wrażliwość ludzką, odczucie radości i podniosłości wobec zespolonej 
wielości. Prowadzący ten zespół zwrócił uwagę, że Gruzini, jak i większość narodów, zawsze żyli we wspólnotach, wyrażali siebie, swoje uczucia, troski i radości śpiewem. Śpiew wynikał z potrzeby ukazania różnych stanów wewnętrznych, był potrzebą dzielenia się całą gamą przeżyć, rozumienia i wspierania wzajemnego zawsze w kontekście widzenia siebie i swojego życia we wspólnocie. Problem utraty siły wspólnotowości rozpoczął się wówczas, gdy zaczęto żyć w coraz większym komforcie, wolnym rynku, zaczął rozwijać się indywidualizm, nie tylko zaspokajający naturalne potrzeby, ale wyzwalający masę pragnień w konflikcie ze wspólnotą.

W kontekście powyższego sądzę, że istnieje realne zagrożenie dla rozwoju wspólnoty i więzi polifonicznych. Tracąc polifonię coraz rzadziej słyszymy inne głosy, nie potrafimy zauważyć równocześnie kilku samodzielnych głosów-melodii stanowiących muzyczną całość. Coraz częściej natomiast słyszymy szum i dysonanse, brak harmonii, rozbieżność i niezgodność, co powoduje konflikty i wyzwala lęki. Sądzę, że obecnie niewiele spośród narodów słowiańskich jest w stanie zaprosić na udany koncert polifoniczny, $\mathrm{z}$ pewnością podobnie jest $\mathrm{z}$ innymi narodami europejskimi, które przecież powstawały i rozwijały się na bazie wspólnych wartości kultury judaistycznej i chrześcijańskiej, filozofii greckiej i prawa rzymskiego. Problemem jest powolna utrata polifonii $w$ procesie kreowania tożsamości narodowej, niezauważanie innych kultur i ich wartości, wykluczanie niejednorodnych kulturowo ze wspólnoty narodowej. Nie chodzi tu o wspólne wartości, jedność, ale o uznanie, zrozumienie i szacunek dla samodzielnych melodii, które składają się na całość i równocześnie mogą służyć rozwojowi wspólnoty regionalnej, narodowej, europejskiej. Stąd niejednokrotnie nawiązuję do filozofii dialogu J. Tischnera i A. Schweitzera [1981], laureata pokojowej nagrody Nobla, twórcy zasady czci do życia, etyki poszanowania życia. Ci i wielu innych intelektualistów wskazywało nam, że interakcje z „Innym” są procesem - drogą nabywania pokory i wrażliwości, uświadomieniem sobie, że jesteśmy Ludźmi o tyle, o ile potrafimy być dla Drugiego.

Albert Schweitzer zwraca uwagę na niebezpieczeństwo neoprymitywizmu, co przejawia się brakiem szacunku do podstawowych wartości humanistycznych w zachowaniach ignorujących podstawowe normy życia społecznego. Należałoby zastanowić się, czy nie jesteśmy obecnie na tej fali, na fali neoprymitywizmu.

Sądzę, że jesteśmy i z pewnością każdy z nas wymieni wiele różnorodnych powodów. Moim zdaniem, dzieje się tak dlatego, że zapominamy o genetycznym prawie rozwoju kulturowego wskazywanego przez Lva Semonovica Wygotskiego. Zostało ono sformułowane następująco: 
(...) w kulturowym rozwoju człowieka każda funkcja pojawia się na scenie dwukrotnie, to znaczy, na dwóch planach. Najpierw pojawia się na planie społecznym, a następnie na planie psychologicznym. Najpierw wśród ludzi jako kategoria interpsychiczna, a następnie wewnątrz każdego z nas jako kategoria intrapsychiczna. To samo stosuje się w przypadku uwagi wolicjonalnej, pamięci logicznej, tworzenia pojęć i rozwoju czynności wolicjonalnych [Veresov 2009: 48].

Jak podkreśla Nikolai Veresov, w pierwszej kolejności mamy relacje między ludźmi (interpsychiczne), a następnie wewnątrz (intrapsychiczne), w obrębie intrapsychicznego systemu samoorganizacji osoby. A więc najpierw jako zbiorowa, społeczna aktywność, a następnie indywidualna aktywność. Wygotski wskazywał, że „każda wyższa funkcja psychiczna, zanim stanie się wewnętrzną funkcją psychiczną, wcześniej była społeczną relacją między dwojgiem ludzi. (...) Wszystkie funkcje psychiczne są zinternalizowanymi relacjami społecznymi” [Veresov 2009: 49]. Czy o tym nie zapomnieliśmy, że interakcje - wspólnota - więzi są podstawą rozwoju człowieka, a nie pragnienia i aspiracje indywidualne.

Opracowując odpowiednie do warunków i obecnej sytuacji strategie edukacyjne mamy świadomość, że to nie grupy, a osoby ulegają asymilacji, zauważamy płaszczyzny, na jakich zachodzi asymilacja ekonomiczna, polityczna, społeczna, psychologiczna, symboliczna i inne. Zauważyliśmy moc grupową, walkę o prawa kulturowe; nazwisko, język, religię. Zastanawiamy się i pytamy, czy jest możliwe w społeczeństwach wielokulturowych prawo do własnych norm, realizowania się po swojemu we wszystkich orientacjach, czy może należy powrócić do polityki asymilacji i akulturacji, przyjmując, że kultura większościowa ma prawo narzucić mniejszościom warunki i zasady przebywania $\mathrm{w}$ ich kraju. Zastanawiamy się także nad problemem europejskiego obywatelstwa i pytamy, co uczynić, aby Europejczycy czuli się Europejczykami nie tylko w sferze konsumpcji, ekonomii, pomocy służb socjalnych? A może ukształtować z imigrantów głównie wspólnotę konsumentów i tą drogą asymilować, włączając w proces kształcenia i załatwianie praw podmiotowych. Może nie realizować praw socjoekonomicznych i kolektywnych, nie reagować i pozwolić ludziom $\mathrm{z}$ różnych kontekstów kulturowych żyć „po swojemu”, skończyć z fikcją równości i dokonać rewizji relatywizmu kulturowego i politycznej poprawności, nie dopuszczać do oznakowania i zawłaszczania przestrzeni kulturowej.

Chciałbym także zwrócić uwagę na budowanie w nowej wielokulturowości wspólnych przestrzeni symbolicznych, określenia wartości i znaczenia pojęcia nacjonalizm, patriotyzm i kosmopolityzm. Współczesny patriotyzm 
winien być oparty na odpowiedzialności za wspólnotę, niewykluczający nikogo, krytyczny wobec historii i jednocześnie zachowujący szacunek do dziedzictwa przodków. Winniśmy więc podjąć problematykę odmian patriotyzmu, poczynając od romantyczno-martyrologicznego aż do patriotyzmu cywilizacyjnego, kosmopolitycznego, próbować odpowiadać, czy patriotyzm to kult bohaterów, ofiara, męczeństwo, czy odpowiedzialność za wspólnotę i codzienna, rzetelna praca, jak kształtować patriotyzm nieagresywny, niewykluczający nikogo, szanujący siebie i dorobek innych narodów.

W kontekście powyższego przed edukacją międzykulturową wiele wyzwań i zadań związanych $\mathrm{z}$ procesem kreowania otwartej polityki wielokulturowości, upominania się o zmiany $\mathrm{w}$ wiodących funkcjach $\mathbf{w}$ wielu krajach Europy i świata; z dominujących militarno-obronnych i ekonomicznych na społeczno-kulturowe, związane $\mathrm{z}$ ochroną wspólnego dziedzictwa kulturowego, zabezpieczaniem twórczego rozwoju człowieka w warunkach wielokulturowości. Edukacja międzykulturowa, bazując na etyce afirmacji świata, poszanowania życia, na wielu teoriach i koncepcjach, poczynając od naszych teorii i koncepcji, np. od Teorii Zachowań Tożsamościowych Tadeusza Lewowickiego do teorii zachowania pokoju Albera Schweitzera, czy paradygmatu pokojowego współistnienia, wydaje się wypełniać swoją rolę przeciwstawiając się koncentracji państw na ratowaniu systemu ekonomicznego, bankowego, militarnego. Zauważamy, że tolerancja dla nacjonalizmów, tym szybciej wzrasta, im większe jest rozczarowanie demokracją. Uważam, że tak jak dbamy o stabilność gospodarczą winniśmy dbać o poczucie bezpieczeństwa obywateli, wartości i zasady życia społeczno-kulturowego, aby nie dopuścić do upadku wiary w człowieka, jego ufność i kulturę wspólnotowości.

\section{Wnioski}

Wieloletnie doświadczenia wskazują, że nie możemy stosować jednej strategii w edukacji międzykulturowej, strategii efektywnie realizującej idee i zasady demokratycznych społeczeństw wielokulturowych. Edukacja międzykulturowa proponuje wielkie bogactwo praktyk edukacyjnych i społecznych o różnym charakterze na poziomie lokalnym, regionalnym, narodowym, międzynarodowym, praktyk polegających na uwzględnieniu w działaniach potrzeb, oczekiwań, aspiracji, prawa do zachowania własnej kultury i kreowania zasad współżycia i współodpowiedzialności za 
określoną przestrzeń życia społecznego. W Katedrze Edukacji Międzykulturowej UwB wskazujemy na symetryczną strategię działań edukacyjnych, oddolnych i odgórnych, w odróżnieniu od nieudanych jednostronnych, liberalno-populistycznych. Stąd w pracy edukacyjnej każdego typu instytucji ukierunkowanej ku kreowaniu społeczeństw wielokulturowych ważna jest znajomość i przestrzeganie prawa, poczynając od Powszechnej Deklaracji Praw Człowieka ONZ i znanych Konwencji (o prawach dziecka, zwalczania dyskryminacji w dziedzinie oświaty, statusu uchodźcy pracowników migrujących, o ochronie mniejszości narodowych i innych). Podobnie istotna jest świadomość zapisów w Europejskiej Karcie Języków Regionalnych i Mniejszościowych Rady Europy, Deklaracji w sprawie mniejszości narodowych oraz Deklaracji w sprawie zwalczania rasizmu, ksenofobii, antysemityzmu i nietolerancji. Nie mniej istotne są zapisy konstytucyjne i dokumenty dotyczące zasad edukacji w warunkach wielokulturowości - dyrektywy, programy, deklaracje (np. dyrektywa Rady Europy z 29 czerwca 2000 roku wprowadzająca zasadę równego traktowania osób niezależnie od ich rasy lub pochodzenia etnicznego czy z 25 listopada 2003, dotycząca statusu obywateli państw trzecich, jak też Deklaracja ateńska - Edukacja międzykulturowa w nowym kontekście europejskim z 2003 roku).

Obecnie edukacja międzykulturowa staje przed istotnym wyzwaniem „przepracowania” funkcjonujących mitów, stereotypów, uprzedzeń w celu „uwolnienia się" świadomościowego i ideologicznego od ich negatywnego wpływu niszczącego zasady kształtowania się społeczeństw wielokulturowych. Uważam, że edukacja szkolna traktowana jest jako istotny instrument władzy politycznej, a więc nie rezygnuje $z$ mitotwórczej apologetyki, poczynając od mitu wspólnego pochodzenia, kończąc na wielu mitach edukacyjnych. Pełniły i pełnią one różne funkcje, odgraniczając od innych, umożliwiając identyfikację i integrację narodową, podtrzymując i utrwalając wyobrażenie o własnym narodzie, dostarczając argumentów o losach i czynach przodków, przewadze duchowej i moralno-etycznej w stosunku do sąsiednich narodów, religii, wyznań.

Jesteśmy przeciwni strategii asymilacji projektowanej, stąd proponujemy strategie wielokulturowości wielopoziomowej i wielopłaszczyznowej, uzupełniającej się na bazie integracji obywatelskiej z poszanowaniem prawa do różnicy. W realizowanych działaniach z zakresu edukacji międzykulturowej podejmowaliśmy próby wypracowania strategii w powyższym zakresie, aby nie konstruować zranionej tożsamości, nie prowadzić do odczuwania poczucia gorszości, a wręcz odwrotnie, doprowadzić do odczuwania poczucia wartości i godności w wyniku wzbogacenia kulturowego, zrozumienia 
i nabycia wrażliwości w kontaktach z reprezentantami innych kultur. W tym kontekście nawiązywałem wielokrotnie do kategorii pogranicza świadomościowego, treściowego i interakcyjnego. Konflikt kulturowy może istnieć w świadomości jednostki w całym procesie życiowym, jednak nie musi wytworzyć antagonistycznej ideologii i wrogich nastawień. Jak wskazywał Albert Schweitzer [1971: 11] „Pierwszym naszym etycznym osiągnięciem jest rozszerzenie kręgu solidarności z innymi ludźmi”. [...] „Ten, kto ma odwagę sądzić i osądzać samego siebie, staje się coraz lepszy”.

\section{Bibliografia}

Angutek D. (red.), Przyszłość wielokulturowości w Polsce. Nowe wyzwania dla antropologii kulturowej $i$ etnologii, przygotowywana do wydania przez Polskie Towarzystwo Ludoznawcze

Babiński G. (1997), Pogranicze polsko-ukraińskie. Etniczność - zróżnicowanie religijne tożsamość, Kraków

Boski P. (2008), Wielokulturowość i psychologia dwukulturowej integracji, [w:] H. Mamzer (red.), Czy klęska wielokulturowości, Poznań

Burszta W. (1997), Wielokulturowość. Pytania pierwsze, [w:] M. Kempny, A. Kapciak, S. Łodziński (red.), U progu wielokulturowości. Nowe oblicza społeczeństwa polskiego, Warszawa

Golka M. (1997), Oblicza wielokulturowości, [w:] M. Kempny, A. Kapciak, S. Łodziński (red.), U progu wielokulturowości, Warszawa

Kurczewska J. (1997), Odkrywanie wielokulturowości i współczesne ideologie, [w:] M. Kempny, A. Kapciak, S. Łodziński (red.), U progu wielokulturowości. Nowe oblicza społeczeństwa polskiego, Warszawa

Mucha J. (1999), Wielokulturowość etniczna i nieetniczna, „Sprawy Narodowościowe. Seria Nowa" z. 14-15

Schweitzer A. (1971), Życie, przeł. J. Piechowski, Warszawa

Schweitzer A. (1981), Z mojego życia..., Warszawa

Szlachta B. (2006), Brytyjska wielokulturowość?, [w:] K. Golemo, T. Paleczny, E. Wiącek (red.), Wzory wielokulturowości we współczesnym świecie, Kraków

Welsch W. (1998), Wielość a niezróżnicowanie, przeł. B. Susła, J. Wietecki, [w:] R. Kubicki (red.), Filozoficzne konteksty rozumu transwersalnego. Wokót koncepcji Wolfganga Welscha, cz. 2, Poznań

Veresov N. (2009), Rozwój kulturowy rozumiany w kategoriach dramatu. Brakujace ogniwo czy ukryte przesłanie L. S. Wygotskiego?, „Teraźniejszość - Człowiek - Edukacja” nr $1(45)$ 
Abstract

\section{Towards which intercultural education strategies in the context of contemporary problems of multiculturalism?}

The author draws attention to the challenges and tasks of intercultural education in the context of contemporary problems related to the implementation of the dilemmas and principles of multiculturalism. Multiculturalism is treated and analysed not only as the coexistence of different cultural groups in the same space, but primarily as an identity, ideological and educational phenomenon that allows to notice, point and deliver new strategies in intercultural education.

The prospect of emancipation, polyphony, J. Tischner's philosophy of dialogue, ethics of respect for life by A. Schweitzer, genetic law of cultural development by L. S. Vygotsky and the changes of countries functions from military-defensive and economic towards social and cultural, are the basics to formulate the strategies for intercultural education and the development of democratic multicultural societies. By referring to the twenty years of actions that have been undertaking by the Department of Intercultural Education at the University of Bialystok, the author indicates the diversity of educational and social practices of different nature at local, regional, national and international levels. These practices are based on considering in these activities the needs, expectations and aspirations of majority and minority groups about the right to preserve their own culture and the creation of rules of coexistence and shared responsibility for socio-cultural area that is culturally diverse.

\section{Keywords:}

culture, multiculturalism, multicultural societies, intercultural education 